\title{
THE IMPACT OF THE TICK SIZE REDUCTION ON LIQUIDITY: Empirical Evidence from the Jakarta Stock Exchange
}

\author{
Lukas Purwoto \\ Eduardus Tandelilin
}

\begin{abstract}
OnJuly 3, 2000, the Jakarta Stock Exchange (JSX) reduced its tick size from Rp25.00 to Rp5.00. This study examines the impact of the tick size reduction on the JSX bid-ask spread, market depth, and trading activity. Using daily data, this study finds that the rupiah spread, percentage spread, and depth decreased significantly. All of these findings are not surprising since they are consistent with previous studies conducted in several different markets.

In contrast to previous studies, this study finds that the key variable in determining the difference in performance of JSX stocks following the tick size reduction is the price of the stock. Specifically, all the trading activity measures e.g. in the number of trades, share volume, and rupiah volume, increased for low-priced stocks. Conversely, trading activity decreased for high-priced stocks. The possible explanation is that absolute tick size Rp5.00 is too small in economic terms for JSX high-priced stocks, so those decrease the investors' willingness to trade.
\end{abstract}

Keywords: Jakarta Stock Exchange; liquidity; tick size 


\section{Introduction}

The Jakarta Stock Exchange (JSX) uses a single absolute tick size (minimum price variation). The tick size implies that both quoted and trading prices to all traded stocks must be stated in terms of this basic unit. On July 3, 2000 the JSX reduced the tick size from Rp25.00 to Rp5.00. As the JSX stated:

This change is implemented in order to create the fair, transparent and efficient trading and to increase the stock-market liquidity. Several researches which were conducted at the other exchanges showing that the lower tick price causing the increase of stock volume and the decrease of bid-offer spread. ${ }^{1}$

Several exchanges have really reduced the tick size in the last decade, and these events have been studied carefully. Bacidore (1997), Porter and Weaver (1998), and Ahn et al. (1998) analyze the impact of the tick size reduction in April 1996 on the Toronto Stock Exchange. Ronen and Weaver (1998) study the tick sizereduction in March 1997 on the American Stock Exchange. Smith (1998) and Bessembinder (1999) examine the Nasdaq tick size reduction in June 1999. Ricker (1998), Goldstein and Kavajecz (2000), and Jones and Lipson (2000) analyze the tick size reduction in June 1997 on the New York Stock Exchange. The JSX could learn a lot from these previous studies; however, all of them examine US and Canada markets.

The trading system at the JSX is different from these markets in at least two respects. First, the JSX is a fully order driven market without any designated market maker. Multiple dealers in Nasdaq or specialists in the New York Stock Exchange and the American Stock Exchange assume a pivotal role in providing liquidity to the market and permit continuous trading by overcoming the asynchronous timing of investor orders. The presence of a market maker is important because the previous studies (for example Goldstein and Kavajecz 2000 and Ronen and Weaver 1998) find that the tick size reduction has affected market maker strategy and behavior thus also affected the spread and other variables. For example, the specialist may "stop" a market order in an attempt to execute the order at a better price and, as a result, the spread decreases.

Secondly, the JSX is a highly transparent market. Everybody can see the entire limit order book and identity the different dealers. Moreover, there areno "hidden orders" that are invisible to traders. The market transparency could result in a less compelling quote matcher argument (Niemeyer and Sandas 1994).

The purpose of this paper is to expand the empirical studies of the impact of tick size reduction on spread and depth on a market with a market maker to apply to a different trading mechanism, that is, a market without a market maker. The final objective is to evaluate liquidity changes following the JSX tick size reduction from Rp25.00 to Rp5.00. The contribution is clear; because a trading system based on market maker is the exception rather than the rule outside North America. Only a few exchanges in continental Europe operate under this trading system, and there are none in Asia. In fact, among the top 37 stock exchanges outside North America, only three use the market-maker system;

\footnotetext{
${ }^{1}$ Press Release-21/BEJ-Kom/0600, June 27, 2000 (www.jsx.co.id/news).
} 
Purwoto \& Tandelilin-The Impact of the Tick Size Reduction on Liquidity

the rest rely on the order-driven mechanism without designated market maker (Ahn and Cheung 1999).

This paper also completes the previous studies of the tick size on markets without market maker, e.g., Niemeyer and Sandas (1994) in the Stockholm Stock Exchange and Chan and Hwang (1998) in the Stock Exchange of Hong Kong. Both studies differ from this study in that they donot analyze actual events where changes in tick size take place, but instead focus on the changes in the tick size regime. Lau and McInish (1995) have actually studied the impact of the tick size reduction on Stock Exchange of Singapore. However, this study has two limitations: 1 ) the sample size is too small (four stocks) and the event period is too short (four days before and five days after the event). Therefore, their results cannot be generalized to broader stocks as on the JSX because the tick size reduction on JSX applies to all stocks. This paper expands all these three studies in at least two ways: (1) controlling other factors and (2) focusing the extent to which the impact of the changes varies across stocks.

The remainder of the paper is organized as follows. Section 2 provides a review of the previous studies. Section 3 briefly describes the data. Section 4 details and discusses the results. Section 5 concludes and recommends.

\section{Previous Studies}

Harris (1994) is the first study to address these issues. Since the tick size sets the lower boundary of the quoted bidask spread, a reduction in the tick size is likely to decrease the spread, which will increase trading volume since trading is less expensive. However, if the tick is too small, the secondary priority rule (time priority) is not meaningful and the quotematcher problem may rise. ${ }^{2}$ The quotematcher's strategy to use the information contained in existing orders. When a large limit order arrives on the market, traders have incentives to try to step in front of existing orders. In other words, if the tick is too small, buyers can obtain precedence simply by bidding a slightly higher price and sellers can obtain precedence by offering a slightly lower price. Public traders defend themselves from quote-matchers by hiding their orders, by breaking up their orders, and by switching to market order strategies from limit order strategies. These responses lower depth. ${ }^{3}$

The effect of the tick size on liquidity has been empirically studied by examining how stocks trade on different tick sizes. Niemeyer and Sandas (1994) in the Stockholm Stock Exchange, Chan and Hwang (1998) in the Stock Exchange of Hong Kong, and Bessembinder (1997) in the Nasdaq corroborate the arguments in

\footnotetext{
${ }^{2}$ The priority rule used by most markets, including the JSX, is price/time priority. Price priority means that the buy (sell) order at a higher (lower) price has priority over a buy (sell) order at a lower (higher) price. In the event that the buy or sell orders are placed at the same price, the priority will give to the buy or sell order entered earlier (time priority).

${ }^{3}$ A natural relation also exists between spread and depth. As a rule, the greater the spread, the greater the depth, since traders will be willing to sell more at a higher price and buy at a lower price (Bessembinder 1997; Harris 1997).
} 
Harris (1994), showing that tick size is positively related to spread and depth, and negatively related to trading volume.

Most studies seek to investigate the effect of tick size changes on liquidity by studying actual markets where such changes take place. Bacidore (1997), Ahn et al. (1998), and Porter and Weaver (1997) study the impact of the April 15, 1996 Toronto Stock Exchange's (TSE) reduction in the minimum tick size. These studies find a significant decline in the quoted spread and in the quoted depth, while the average trading volume displayes no statistically significant increase. The authors argue that the smaller tick size had at worst no effect and at best a liquidity improving effect on the TSE because of the dramatic decrease in spreads and despite the decrease in quoted depth.

On July 18, 1994, the Stock Exchange of Singapore reduced the minimum price increment from 50 cents to 10 cents for stocks priced over 25 dollars. But the rule change affected only five stocks, of which only three traded substantially both before and after the change. Lau and McInish (1995) find that quoted spread and depth decreased, but there was no apparent change in volume. Their findings on reduced spread lead them to conclude that the tick size reduction increased market quality.

Ronen and Weaver (1998) study the impact of the May 7, 1997 switch to sixteenths by the American Stock Exchange. Their results, conditioning the sample by price level and trading volume, are similar to other earlier empirical studies. Their observation of reduced quoted spread and depth (but not of increased volume) causes the authors to conclude that the implemented reduction to the tick size has decreased transaction costs and increased liquidity.
Ricker (1998) conducts analyses of the tick size reduction on the New York Stock Exchange in June 1997. He finds that the quoted spread and depth declined and volume increased. Then, he calculates that the tick size reduction saved $\$ 1.8$ billion in trading costs. He concludes clearly that liquidity increased and he suggests a tick size of one cent. As addition, the Nasdaq also reduced the tick size in June 1997. Smith (1998) analyzes this event and also finds the decline in spread and depth.

However, the impact of the tick size reduction on liquidity is still in dispute. Goldstein and Kavajecz (2000) show that while both spread and depth (quoted and on the limit order book) declined after the New York Stock Exchange's change from eighths to sixteenths, cumulative depth declined throughout the entire limit order book as well. The combined effect of smaller spread and reduced cumulative limit order book depth has made the cost of executing smaller orders come down, but execution costs for larger orders neither did see any benefits (for frequently traded stocks) or see an increase in costs (for infrequently traded stocks). Thus, in contrast to previous studies that found liquidity increases after the tick size reductions, Goldstein and Kavajecz (2000) do not find evidence of additional liquidity for some market participants.

Finally, using institutional data, Jones and Lipson (1998) examined the effects of the change in tick size on the New York Stock Exchange and the Nasdaq. Though quoted and effective spreads declined, realized execution costs for these institutions increased post-sixteenths. They argue that spreads are not a sufficient statistic for market quality, and smaller ticks may actually reduce market liquidity. 
Given the findings of the studies, the appropriateness and effects of the reduction in tick size remain open to debate. Supporters argue that smaller tick sizes benefit liquidity demanders, as competition between liquidity providers is likely to force a reduction in the bid-ask spread. As a result, trading cost to investors is reduced and trading volume will increase. Opponents counter that a lower tick size increases the possibilities of professional traders to step in front of public limit orders. Consequently, depth will decline, the markets will become less transparent, transaction cost mayincrease, and trading volume will decline.

\section{Data and Methodology}

This studyutilizes daily data from the List of Securities Quotations published by the JSX. ${ }^{4}$ The sample period is from May 1 to August 31, 2000, and is divided into two sub-periods of approximately equal length, the pre-reduction period (May 1, 2000 to June 30,2000$)$ and the post-reduction period (July 4, 2000 to August 31, 2000). The event date is July 3,2000 , the day on which the JSX adopted the new tick.

Among the 286 common stocks listed on the exchange, this study excludes 93 stocks, leaving a total of 193 stocks in the sample, based on the following criteria:

(1) Stocks that were delisted by the JSX during the sample period (2 stocks).

(2) Stocks that experienced a split (or stock dividend) during the sample pe$\operatorname{riod}(8$ stocks).

(3) Stocks with less than one quote and one trade for either the pre- or postevent period (32 stocks).

(4) Stocks which averaged less than one transaction per day for either the preor post-event period (51 stocks).

Goldstein and Kavajecz(2000), Smith (1998), Ronen and Weaver (1998), and Porter and Weaver (1997) - each using data from New York Stock Exchange, Nasdaq, American Stock Exchange, and Toronto Stock Exchange - also find that the impact of the tick size reduction is sensitive to price and trading activity. To test if pre-reduction price and volume are a determinant of the impact of tick size reduction, this study examines the sample stocks in price/volume quadrants. Stocks were placed in one of four quadrants according to their joint price and volume ranking (high or low). If the tick size was a binding constraint on the spread, the data should show a clustering of quotes at the minimum spread (one tick). Table 1 contains descriptive statistics for the sample in the price/volume quadrants. ${ }^{5}$ The percentage of observed Rp25.00 spread

\footnotetext{
${ }^{4}$ List of Securities Quotations includes stock code, name, closing price, opening price, trading frequency, volume in shares, volume in rupiah, and price and number of shares at the best closing quote. The data comes from quotes and trade of regular market. Orders placed on the Regular Board are matched through JATS (Jakarta Automated Trading System) according to price and time priority; only limit orders may be entered, or alternatively all orders (as market order) can be viewed as limit orders. Except regular board, the JSX also provides a negotiated market. The securities trading at the negotiated market, however, are conducted through the process of individual bid and offer (direct negotiation) between Exchange Members.

5 The correlation among the three price measures (closing price, opening price, and bid-ask midpoint) and between both trading activity measures (trading frequency and share volume) are close to one, thus the choice of the proxies is the arbiter. This study chooses the closing price and share volume since people are familiar with both measures as indicators of movement of stock trading. Closing price and share volume is not significantly correlated (-0.029). It becomes clear that joining both variables should partition the sample into subsamples. If both measures were highly correlated, then using price as the partitioning variable would result in opposite findings.
} 
Table 1. Descriptive Statistics

\begin{tabular}{|c|c|c|c|}
\hline \multirow{2}{*}{ Price Level } & & \multicolumn{2}{|c|}{ Volume Level } \\
\hline & & Low & High \\
\hline \multirow{4}{*}{ Low } & Average Price (Rp) & 297.71 & 276.58 \\
\hline & Average Volume (Shares) & $155,399.44$ & $2,865,094.75$ \\
\hline & Average $\%$ of Rp 25 spread & 70.86 & 93.11 \\
\hline & $\mathrm{N}$ & 47 & 49 \\
\hline \multirow{4}{*}{ High } & Average Price (Rp) & $3,520.51$ & $2,078.81$ \\
\hline & Average Volume (Shares) & $109,637.99$ & $3,733,974.70$ \\
\hline & Average $\%$ of Rp 25 spread & 44.38 & 88.69 \\
\hline & $\mathrm{N}$ & 49 & 48 \\
\hline
\end{tabular}

(spread equals one tick) is found to be inversely related to price and positively related to trading activity. For example, a Rp25.00 spread of infrequentlytraded lowpriced stocks is averaged at 44 percent of the closing time. ${ }^{6}$ Therefore, the decrease in spread would be most significant for stocks that now trade most of the time at minimum spread, that is, low-priced and frequently traded stocks as Harris (1994) points out.

The table shows average closing price, average daily share volume, average percentage of Rp25.00 spread, and the number of stocks in the sample. Groups were formed by ranking stocks by average price and separately by average daily volume for the period of May 1 to June 30, 2000 (pre-reduction period). Stocks were then placed in one of four quadrants according to joint price and volume ranking (high or low).

\section{Results and Discussion}

\section{Spread}

First, time-series averages of spread measures (and other variables) are calculated in the pre-reduction and post-reduction periods for each stock. Then the crosssectional statistics (means, standard deviations, etc.) are calculated from the timeseries averages for each period. Two statistical tests, the parametric paired $t$-test and non-parametric sign test, are used to test whether the change in the variable from pre- to post-reduction period is significant. The purpose of the parametric paired $t$-test is to investigate the change in mean value, while the non-parametric sign test focuses on the significance of the proportion of the stocks experience changes. Moreover, frequency distribution of the observed variables is skewed,

\footnotetext{
${ }^{6}$ As comparison, Harris (1994) shows that 45 percent of all New York Stock Exchange stocks were quoted at one tick (\$1/8) spread in 1989. Ricker (1998) shows that in the pre-event period, the New York Stock Exchange stocks in his sample were quoted at the minimum $\$ 1 / 8$ spread 59 percent of the time.
} 
and thus does not conform well to the normality assumption.

Following the most common way to measure spread, this study calculates rupiah spread and percentage spread. Rupiah spread is defined as $A_{j, t}-B_{j, t}$, where $A_{j, t}$ and $B_{j, t}$ are the best ask and bid price for stock $j$ at day $t$. Percentage spread, expressing spread as a percentage of price, is defined as spread rupiah divided by the midpoint of the quote [defined as $\left[\mathrm{A}_{\mathrm{j}, \mathrm{t}}+\right.$ $\left.\left.\mathrm{B}_{\mathrm{j}, \mathrm{t}}\right) / 2\right]$.

The results are given in Panel $A$ of Table 2. The mean rupiah spread Rp72.54 is much too high compared to the tick of Rp25.00 in the pre-reduction period and Rp59.90 is also too high when compared to the tick of Rp5.00 in the post-reduction period. More important is that both the rupiah and percentage spread were significantly reduced after the tick size reduction. The mean decline in therupiah spread is Rp12.64, and 5.30 percent in the percentage spread, or decreases 17.42 percent and 52.66 percent from the pre- to post- reduction period. About 85 percent of the sampleexperienced a decline in both spread measures. All test statistics, from both the parametric paired $t$-test and non-parametric sign test, reject the null hypothesis that there is no change in the rupiah spread or the percentage spread from the pre- to the post-event period. And toascertain whether the spread reduction was sensitive to event period choice, both pre- and post-reduction periods are shortened to one month. The results in Panel $B$ of Table 2 shows that spread significantly decreased, consistent with previous results. The selection of the event period does change the findings.

Table 2 shows the average spread measured by rupiah spread and percentage spread during the pre-reduction period and the post-reduction period. In Panel $A$, the pre-period is May 1 to June 30, 2000 and the post-period is July 4 to August 31, 2000. In Panel B, the pre-period is June 1 to June 30,2000 and the post-period is July 4 to July 31,2000 . These periods surround

Table 2. Comparison of Pre- and Post-Reduction Spread

\begin{tabular}{|c|c|c|c|c|c|c|}
\hline & Before & After & Change & t-statistic & $\begin{array}{c}\text { \% of } \\
\text { stocks } \\
\text { with } \\
\text { decline }\end{array}$ & $z$-statistic \\
\hline \multicolumn{7}{|c|}{ A: Event Period (May, June) and (July, August) } \\
\hline Rupiah Spread & 72.54 & 59.90 & -12.64 & $-1.78 *$ & 84.97 & $-9.65 * * *$ \\
\hline Percentage Spread & 10.07 & 4.77 & -5.30 & $-9.78 * * *$ & 86.01 & $-9.93 * * *$ \\
\hline \multicolumn{7}{|c|}{ B: Event Period (June) and (July) } \\
\hline Rupiah Spread & 69.77 & 57.57 & -12.21 & $-2.41 * *$ & 84.38 & $-9.45 * * *$ \\
\hline Percentage Spread & 10.12 & 4.69 & -5.43 & $-10.56 * * *$ & 86.98 & $-10.18 * * *$ \\
\hline \multicolumn{7}{|c|}{$\begin{array}{l}* \text { Significant at the } 0.10 \text { level } \\
* * \text { Significant at the } 0.05 \text { level } \\
* * * \text { Significant at the } 0.01 \text { level }\end{array}$} \\
\hline
\end{tabular}


Gadjah Mada International Journal of Business, May 2004, Vol. 6, No. 2

the JSX tick size reduction, which occurred on July 3, 2000. Also reported is the average change between the two periods. The $t$-statistic is calculated by using a parametric paired $t$-test to test the null hypothesis that the mean change is zero. The $z$-statistic is calculated by using a nonparametric sign test to test the null hypothesis that the percentage of the stocks that experienced a decline equals 50 .

Table 3. Comparison of Pre- and Post-Reduction Spread by Price and Volume

\begin{tabular}{|c|c|c|c|}
\hline \multirow{2}{*}{\multicolumn{2}{|c|}{ Price Level }} & \multicolumn{2}{|c|}{ Volume Level } \\
\hline & & \multirow[t]{2}{*}{ Low } & \multirow[t]{2}{*}{ High } \\
\hline$A: R u p i$ & & & \\
\hline \multirow{6}{*}{ Low } & Before & 41.63 & 27.62 \\
\hline & After & 21.45 & 8.59 \\
\hline & Change & -20.18 & -19.03 \\
\hline & $t$-statistic & $-6.86 * * *$ & $-18.98 * * *$ \\
\hline & $\%$ of stocks with decline & 93.62 & 97.96 \\
\hline & $z$-statistic & $-5.84 * * *$ & $-6.57 * * *$ \\
\hline \multirow{6}{*}{ High } & Before & 189.27 & 29.50 \\
\hline & After & 191.25 & 15.84 \\
\hline & Change & 1.98 & -13.66 \\
\hline & $t$-statistic & 0.07 & $-10.29 * * *$ \\
\hline & $\%$ of stocks with decline & 57.14 & 91.67 \\
\hline & $z$-statistic & -0.86 & $-5.63 * * *$ \\
\hline \multicolumn{4}{|c|}{ B: Percentage Spread } \\
\hline \multirow{6}{*}{ Low } & Before & 15.69 & 14.06 \\
\hline & After & 7.34 & 3.38 \\
\hline & Change & -8.36 & -10.68 \\
\hline & $t$-statistic & $-6.85 * * *$ & $-9.91 * * *$ \\
\hline & $\%$ of stocks with decline & 93.62 & 97.96 \\
\hline & $z$-statistic & $-5.84 * * *$ & $-6.57 * * *$ \\
\hline \multirow{6}{*}{ High } & Before & 7.84 & 2.75 \\
\hline & After & 7.22 & 1.15 \\
\hline & Change & -0.62 & -1.60 \\
\hline & $t$-statistic & -0.84 & $-8.88 * * *$ \\
\hline & $\%$ of stocks with decline & 61.22 & 91.67 \\
\hline & $z$-statistic & -1.43 & $-5.63 * * *$ \\
\hline \multicolumn{4}{|c|}{$\begin{array}{l}* \text { Significant at the } 0.10 \text { level; } \\
* * \text { Significant at the } 0.05 \text { level; } \\
* * * \text { Significant at the } 0.01 \text { level. }\end{array}$} \\
\hline
\end{tabular}


Purwoto \& Tandelilin - The Impact of the Tick Size Reduction on Liquidity

Figure 1. Time-Series Plot of Percentage Spread

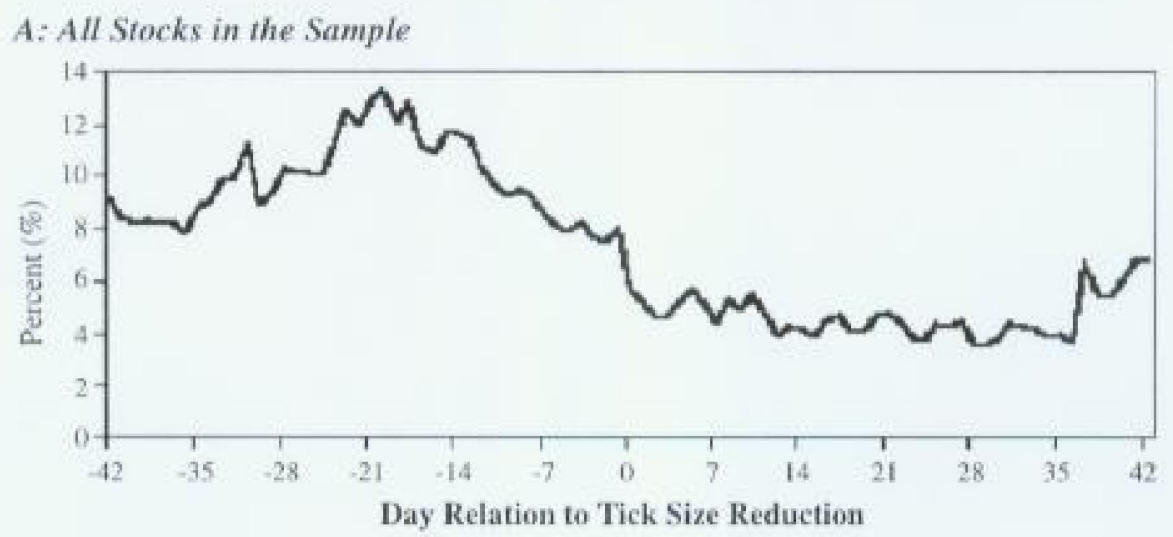

B. Low Price, Low Volume
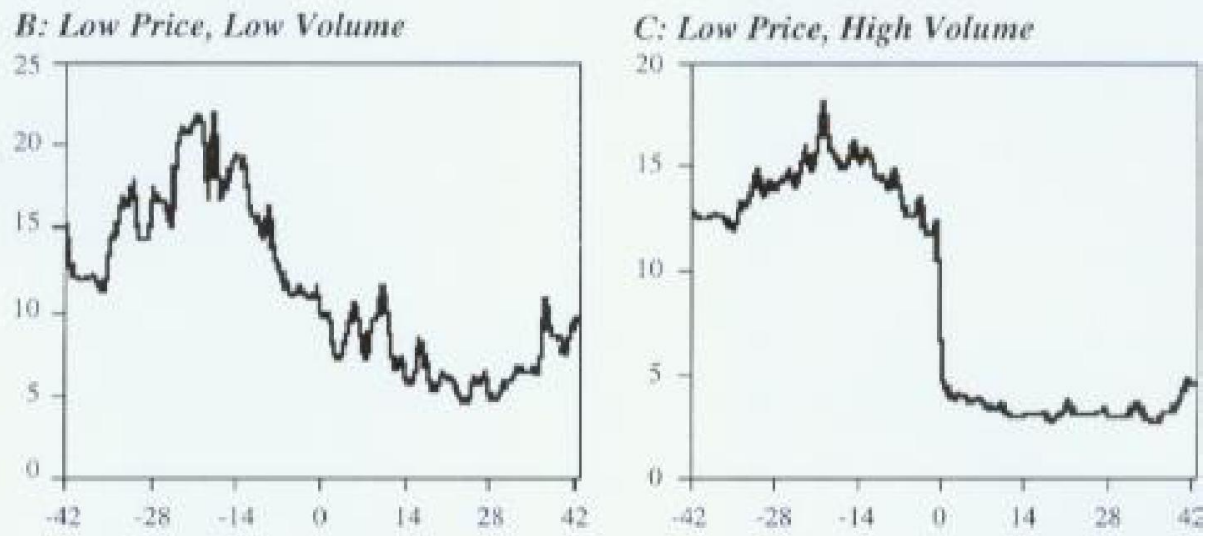

D: High Price, Low Volume
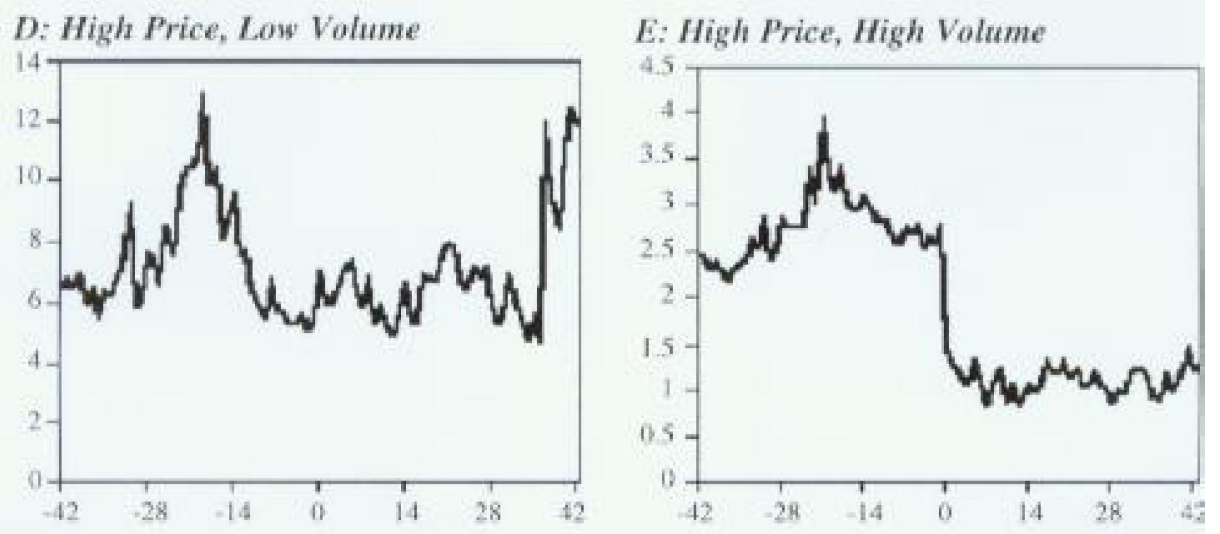
Table 3 reports the results in price/ volume quadrant to examine whether the reduction in spread is sensitive to price and trading activity. Rupiah spread tends to be smaller in lower priced and actively traded stocks (consistent with the regression results in the next subsection). It was found that infrequently traded high-priced stocks did not experience a decline in either rupiah spread or percentage spread, while both spread measures of the other categories were significantly decreased after the tick size reduction. These results suggest that the reduction in spread was larger for lower priced and frequently traded stocks. $^{7}$

The table compares spread in price/ volume quadrant to pre-reduction period (May 1 to June 30, 2000) and post-reduction period (July 4 to August 31, 2000). Also reported is the average change between the two periods. The $t$-statistic is calculated by using a parametric paired $t$ test to test the null hypothesis that the mean change is zero. The $z$-statistic is calculated by using a non-parametric sign test to test the null hypothesis that the percentage of the stocks that experienced a decline equals 50 .

Following Ahn et al. (1998), this study also examines the time-series behavior of the spread. The objective is to investigate whether the spread decreased suddenly after July 3, 2000, or decreased slowly over time. The cross-sectional average of the spread is calculated on each day. Figure 1 presents the time-series plot of the cross-sectional average of the percentage spread. The plot shows that the percentage spread of all stocks in the sample slowly decreased within a few days after the event day. While this occurred for almost all four-quadrant stocks, the spread reduction was most clear-cut for low-priced and frequently traded stocks. Clearly, the graph shows that the Rp25.00 tick size was a binding constraint in the pre-reduction period.

\section{Depth}

The standard measures of depth in the previous studies are at the best quote. This study measures depth by calculating ask-depth (the number of shares at the best ask price), and bid-depth (the number of shares at the best bid price). The depth measures are separated between ask-depth and bid-depth since the changes in depth may be asymmetrical.

Panel $A$ of Table 4 shows the results. Both ask-depth and bid-depth are relatively equal, about 700,000 shares in the pre-reduction period. On average, both depth measures decreased by 400,000 shares or 55 percent from pre- to postreduction period. Most stocks (90 percent) in the sample experienced a decline in depth. Both test statistics, the parametric paired $t$-test and non-parametric sign test, strongly reject the null hypothesis that there is no change in each of the both depth measures. Again, results of the Panel B of Table 4 shows that the choice of the event period does change the findings.

The table shows the average depth in shares measured by ask-depth and biddepth. In Panel A, the pre-period is May 1 to June 30,2000 and the post-period is July 4 to August 31, 2000. In Panel B, the preperiod is June 1 to June 30, 2000 and the

\footnotetext{
${ }^{7}$ Could partitioning into high and low ranking sections give different results? This study also arranged the table showing changes in average spreads by dividing the sample stocks into three equal groups separately based on both price and volume. The results still lead to the conclusion that low-priced and high-volume stocks experience the greater declines.
} 
Purwoto \& Tandelilin-The Impact of the Tick Size Reduction on Liquidity

Table 4. Comparison of Pre- and Post-Reduction Depth

\begin{tabular}{|c|c|c|c|c|c|c|}
\hline & Before & After & Change & $t$-statistic & $\begin{array}{c}\text { \% of } \\
\text { stocks } \\
\text { with } \\
\text { decline }\end{array}$ & $z$-statistic \\
\hline \multicolumn{7}{|c|}{ A: Event Period (May, June) and (July, August) } \\
\hline Ask-depth & 677,393 & 275,584 & $-401,809$ & $-7.18 * * *$ & 90.16 & $-11.09 * * *$ \\
\hline Bid-depth & 680,473 & 323,146 & $-357,327$ & $-7.93 * * *$ & 87.05 & $-10.22 * * *$ \\
\hline \multicolumn{7}{|c|}{ B: Event Period (June) and (July) } \\
\hline Ask-depth & 726,822 & 247,247 & $-479,575$ & $-7.70 * * *$ & 88.54 & $-10.61 * * *$ \\
\hline Bid-depth & 727,776 & 281,071 & $-446,705$ & $-8.29 * * *$ & 90.63 & $-11.19 * * *$ \\
\hline
\end{tabular}

* Significant at the 0.10 level;

** Significant at the 0.05 level;

$* * *$ Significant at the 0.01 level.

post-period is July 4 to July 31, 2000. These periods surround the JSX tick size reduction that occurred on July 3, 2000. Also reported is the average change between the two periods. The $t$-statistic is calculated by using a parametric paired $t$ test to test the null hypothesis that the mean change is zero. The $z$-statistic is calculated by using a non-parametric sign test to test the null hypothesis that the percentage of the stocks that experienced a decline equals 50 .

Since spread reduction is found to be sensitive to price and volume, depth might also be sensitive. Table 5 shows the results of ask depth and bid depth in the price/ volume quadrant. Depths are found to positively relate to volume and negatively relate to price(consistent with the regression results in the next subsection). All four quadrants show that depth decreased and it was significant in both the parametric paired t test and the non-parametric sign test. Though high volume stocks experienced greater absolute declines in depths, the decline was relatively greater for lowpriced and frequently traded stocks.

The table compares depth in price/ volume quadrant to pre-reduction period (May 1 to June 30, 2000) and post-reduction period (July 4 to August 31, 2000). Also reported is the average change between the two periods. The $t$-statistic is calculated by using a parametric paired $t$ test to test the null hypothesis that the mean change is zero. The $z$-statistic is calculated by using a non-parametric sign test to test the null hypothesis that the percentage of the stocks that experienced a decline equals 50 .

Figure 2 presents the time-series plot of the cross-sectional average of ask-depth. For bid-depth, the time series plots show a similar pattern and are not reported. Clearly, the plot shows that the depth of all stocks in the sample abruptly decreased within a few days after the event day. While this occurred for almost all fourquadrant stocks, the depth reduction was most clear-cut for low-priced and fre- 
Gadjah Mada International Journal of Business, May 2004, Vol. 6, No. 2

Table 5. Comparison of Pre- and Post-Reduction Depth by Price and Volume

\begin{tabular}{|c|c|c|c|}
\hline \multirow[b]{2}{*}{ Price Level } & & \multicolumn{2}{|c|}{ Volume Level } \\
\hline & & Low & High \\
\hline \multicolumn{4}{|l|}{ A: Ask-Depth } \\
\hline \multirow{6}{*}{ Low } & Before & 197,550 & $1,769,320$ \\
\hline & After & 70,444 & 876,784 \\
\hline & Change & $-127,106$ & $-892,536$ \\
\hline & $t$-statistic & $-4.10 * * *$ & $-5.38 * * *$ \\
\hline & $\%$ of stocks with decline & 87.23 & 93.88 \\
\hline & $z$-statistic & $-4.96 * * *$ & $-6.00 * * *$ \\
\hline \multirow{6}{*}{ High } & Before & 32,214 & 691,184 \\
\hline & After & 23,347 & 120,215 \\
\hline & Change & $-8,867$ & $-570,969$ \\
\hline & $t$-statistic & -1.15 & $-5.45 * * *$ \\
\hline & $\%$ of stocks with decline & 81.63 & 97.92 \\
\hline & $z$-statistic & $-4.29 * * *$ & $-6.50 * * *$ \\
\hline
\end{tabular}

\section{B: Bid-Depth}

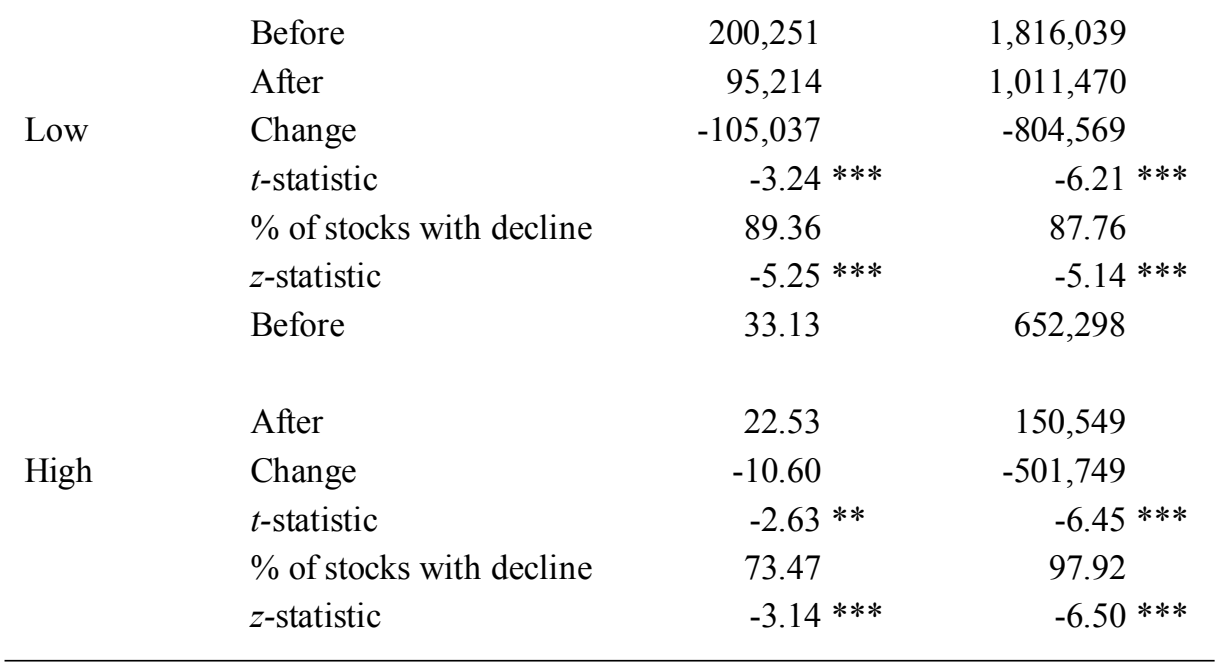

* Significant at the 0.10 level;

** Significant at the 0.05 level;

*** Significant at the 0.01 level. 
Purwoto \& Tandelilin - The Impact of the Tick Size Reduction on Liquidity

Figure 2. Time-Series Plot of Ask-Depth

A: All Stocks in the Sample

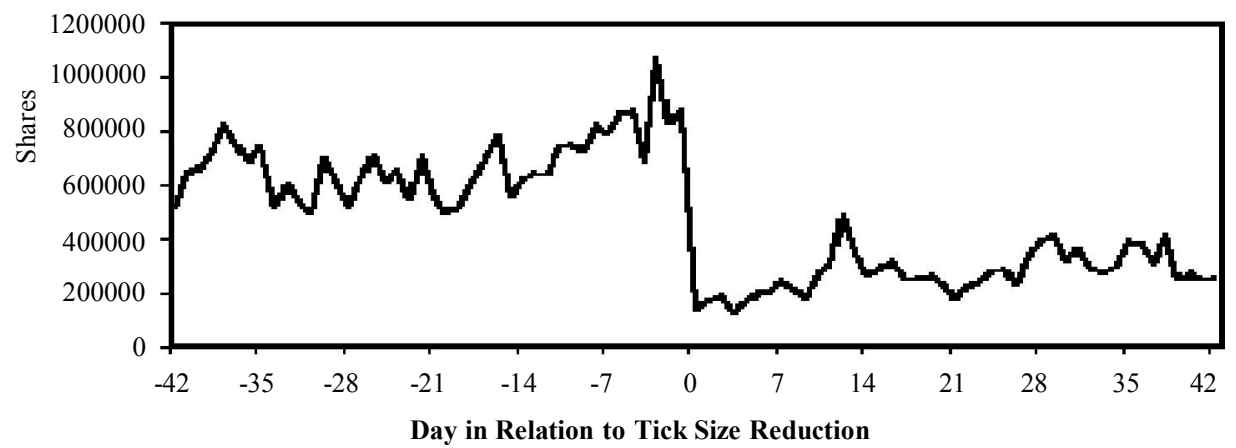

B: Low Price, Low Volume

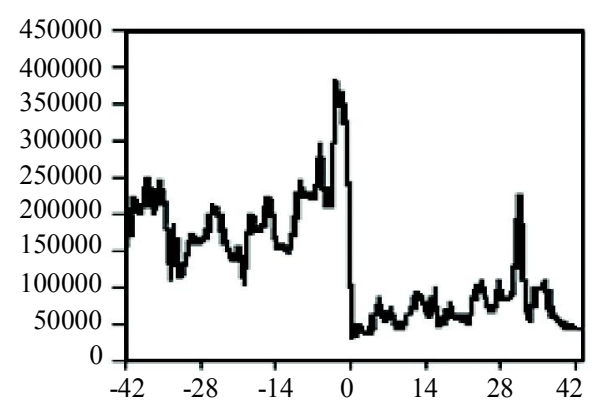

D: High Price, Low Volume

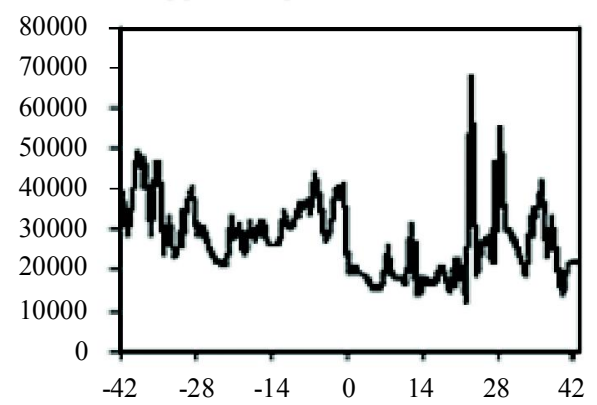

C: Low Price, High Volume

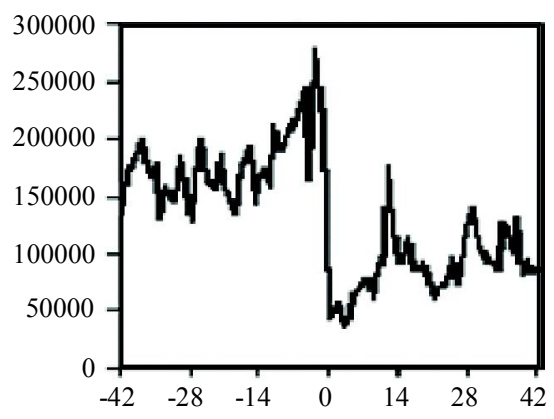

C: High Price, High Volume

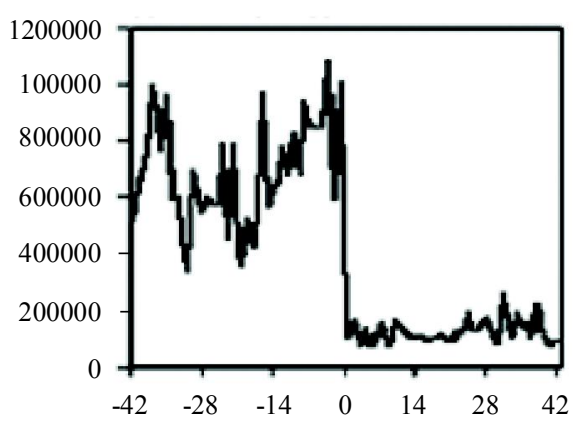


Gadjah Mada International Journal of Business, May 2004, Vol. 6, No. 2

quently traded stocks. The time-series plots confirm that the JSX tick size reduction had a significant impact on the depth.

\section{Controlling for Other Factors}

While the results indicate that both spread and depth decreased after the tick reduction, the observed changes could be due to factors other than the tick size reduction. Market microstructure literature has long noted that spread is a function of price level, trading activity, and volatility, and several later studies also use these factors to explain or control changes in depth. ${ }^{8}$ The cross-sectional regression developed by Porter and Weaver (1997) and Ronen and Weaver (1998) are used here with slight modifications:

$$
\begin{aligned}
\text { Ln LIQUIDITY }_{\mathrm{j}, \mathrm{t}}= & \alpha+\beta_{1}\left(\operatorname{Ln~PRICE}_{\mathrm{j}, \mathrm{t}}\right) \\
& +\beta_{2}(\operatorname{Ln} \operatorname{TRADING} \\
& \text { FREQUENCY }_{\mathrm{j}, \mathrm{t}}+ \\
& \beta_{3}\left(\operatorname{LnVOLATILITY}_{\mathrm{j}, \mathrm{t}}\right) \\
& +\beta_{4}\left(\text { TICKDUMMY }_{\mathrm{j}, \mathrm{t}}\right)
\end{aligned}
$$

Where LIQUIDITY is calculated for spread measures and depth measures for stock $\mathrm{j}$ during period $t$ (pre- or post-reduction period). PRICE is defined as average closing price. TRADING FREQUENCY is the average number of trades per day. VOLATILITY is measured by standard deviation

\begin{tabular}{|c|c|c|c|c|c|c|c|}
\hline $\begin{array}{c}\text { Dependent } \\
\text { Variable }\end{array}$ & Intercept & Price & $\begin{array}{l}\text { Trading } \\
\text { Frequency }\end{array}$ & Volatility & $\begin{array}{c}\text { Tick- } \\
\text { dummy }\end{array}$ & $\mathbf{R}^{2}$ & F-stat \\
\hline Rupiah Spread & $\begin{array}{c}2.51 * * * \\
(17.83)\end{array}$ & $\begin{array}{c}0.71 * * * \\
(33.44)\end{array}$ & $\begin{array}{c}-0.37 * * * \\
(-28.69)\end{array}$ & $\begin{array}{c}0.73 * * * \\
(15.42)\end{array}$ & $\begin{array}{c}-0.41 * * * \\
(-8.62)\end{array}$ & 0.86 & 585.19 \\
\hline Percentage Spread & $\begin{array}{c}7.20 * * * \\
(50.23)\end{array}$ & $\begin{array}{c}-0.29 * * * \\
(-13.41)\end{array}$ & $\begin{array}{c}-0.37 * * * \\
(-28.07)\end{array}$ & $\begin{array}{c}0.75 * * * \\
(15.59)\end{array}$ & $\begin{array}{c}-0.41 * * * \\
(-8.50)\end{array}$ & 0.86 & 589.20 \\
\hline Ask-Depth & $\begin{array}{c}15.41 * * * \\
(42.19)\end{array}$ & $\begin{array}{c}-1.05 * * * \\
(-19.09)\end{array}$ & $\begin{array}{c}0.74 * * * \\
(22.01)\end{array}$ & $\begin{array}{c}-0.28 * * \\
(-2.27)\end{array}$ & $\begin{array}{c}-1.21 * * * \\
(-9.88)\end{array}$ & 0.72 & 239,13 \\
\hline Bid-Depth & $\begin{array}{c}16.27 * * * \\
(47.44)\end{array}$ & $\begin{array}{c}-1.14 * * * \\
(-21.95)\end{array}$ & $\begin{array}{c}0.76 \text { *** } \\
(23.80)\end{array}$ & $\begin{array}{c}-0.18 \\
(-1.60)\end{array}$ & $\begin{array}{c}-1.16 * * * \\
(-10.03)\end{array}$ & 0.76 & 296,82 \\
\hline
\end{tabular}
of daily midpoint quote return. TICKDUMMY is a dummyvariable, which is assigned the value 0 if the period is pre-

Table 6. Regression Results

* Significant at the 0.10 level;

** Significant at the 0.05 level;

*** Significant at the 0.01 level.

\footnotetext{
8 Tinic and West (1974), Cohen et al. (1981), McInish and Wood (1992), Aitken and Frino (1996), Huang and Stoll (1999) show these relations. Trading activity is positively related to spread, since limit orders of thinner stocks have a lower probability of execution so that market participants are less likely to submit limit orders, hence reducing the downward pressure on spreads. Spread tends to be high in high volatility because high volatility hurts the liquidity supplier. The rupiah spread increases with the price level to balance the execution cost; however, the percentage spread is inversely related to price level due to the minimum tick rule. Also, the relation between depth and the three variables is the opposite of rupiah spread.
} 
Purwoto \& Tandelilin-The Impact of the Tick Size Reduction on Liquidity

period and 1 if the period is post-period. If tick size reduction affects changes in spread and depth, the parameter estimate for TICKDUMMY is expected to be significantly different from zero.

Table 6 documents the above regression's results. All control variables are found to be significant with the expected sign. The coefficients of the dummy variable are negative and statistically significant for all the spread measures and depth measures. Thus, it suggests that even after controlling for other factors, the tick size reduction still contribute to the observed reduction in JSX spread and depth.

The table reports the results of the cross-sectional regression for $L n L I Q U I D-$ ITY to Ln PRICE, Ln TRADING FREQUENCY, Ln VOLATILITY, and
TICKDUMMY. LIQUIDITY is calculated for spread measures and depth measures. PRICE is the average closing price. TRADING FREQUENCY is the average number of daily trades. VOLATILITY is measured by standard deviation of daily midpoint quote return. TICKDUMMY is a dummy variable, which is assigned the value 0 if the period is pre-period (May 1 to June 30, 2000) and 1 if the period is post-period (July 4 to August 31, 2000). The $t$-statistics are in parenthesis.

\section{Trading Activity}

Following the previous studies, this study uses three measures to examine the impact of tick size reduction on trading activity: daily number of trades (trading frequency), share volume, and rupiah vol-

Table 7. Comparison of Pre- and Post-Reduction Trading Activity

\begin{tabular}{|c|c|c|c|c|c|c|}
\hline & Before & After & Change & $t$-statistic & $\begin{array}{c}\text { \% of } \\
\text { Stocks } \\
\text { with } \\
\text { Increase }\end{array}$ & $\begin{array}{c}\text { z- } \\
\text { statistic }\end{array}$ \\
\hline \multicolumn{7}{|c|}{ A: Event Period (May, June) and (July, August) } \\
\hline Number of Trades & 78 & 82 & 4 & 0.51 & 48.71 & -0.29 \\
\hline Share Volume & $1,721,743$ & $2,290,617$ & 568,874 & 1.59 & 42.49 & $-2.02 * *$ \\
\hline $\begin{array}{l}\text { Rupiah Volume } \\
(000 \mathrm{~s})\end{array}$ & $1,941,241$ & $1,232,097$ & $-709,144$ & $-2.52 * *$ & 42.49 & $-2.02 * *$ \\
\hline \multicolumn{7}{|c|}{ B: Event Period (June) and (July) } \\
\hline Number of Trades & 88 & 75 & -13 & -1.47 & 38.34 & $-3.10 * * *$ \\
\hline Share Volume & $2,032,488$ & $2,001,741$ & $-30,746$ & -0.09 & 33.68 & $-4.40 * * *$ \\
\hline $\begin{array}{l}\text { Rupiah Volume } \\
(000 \mathrm{~s})\end{array}$ & $2,151,499$ & $1,139,252$ & $-1,012,247$ & $-2.82 * * *$ & 34.72 & $-4.11 * * *$ \\
\hline
\end{tabular}

* Significant at the 0.10 level;

** Significant at the 0.05 level;

*** Significant at the 0.01 level. 
ume. Panel $A$ of Table 7 compares the number of trades, share volume, and rupiah volume from the pre- to post-reduction period. Thenumber of trades increased by four trades per day or 4.93 percent from the pre to post reduction period. The proportion of stocks that decreased is also relativelyequal to those that increased. All test statistics, the parametric paired $t$-tests and non-parametric sign tests, do not reject the null hypothesis that there is no change in the number of trades from the pre- to the post-event period.

The table shows the average daily trading activity measured by number of trades, volume in share, and volume in rupiah during the pre- and post-reduction periods. In Panel $A$, the pre-period is May 1 to June 30, 2000 and post- period is July 4 to August 31, 2000. In Panel B, the preperiod is June 1 to June 30, 2000 and the post- period is July 4 to July 31, 2000. These periods surround the JSX tick size reduction on July 3, 2000. Also reported is the average change between the two periods. The $t$-statistic is calculated by using a parametric paired $t$-test to test the null hypothesis that the mean change is zero. The $z$-statistic is calculated by using a nonparametric sign test to test the null hypothesis that the percentage of the stocks that experienced an increase equals 50 .

A similar analysis is done using the share volume and rupiah volume. Share volume increased on average by 568,874 shares or 33.04 percent. However, this increase is insignificant according to the parametric paired $t$-test. The proportion of stocks that experienced an increase (43 percent) is less than those that decreased (57 percent) and is significant using the non-parametric sign test. Moreover, the results of the rupiah volume even show a decline following the tick size reduction and are significant using both the parametric paired $t$-test and non-parametric sign test.

To ascertain whether the volume changes is sensitive to event period selection, each of the pre- and post-reduction periods is shortened to one month. The results in Panel B of Table 7 show that all three measures of the trading activity did not increase, and generally even indicate a minor decrease in volumes, consistent with previous results. The selection of the event period does not affect the findings.

However, this investigation is not finished yet. This study has showed that the decline in spread is sensitive to price and volume. If the increase in trading activity were due to spread narrowing, it would therefore be expected that the lowpriced and frequently traded stocks exhibit increases in trading activity following the tick size reduction. The overview of Table 8 shows these results. The pattern is explicitly clear: the key variable influencing the variation is the price of the stock. The low-priced stocks experienced an increase in theaverage number of trades, share volume, and rupiah volume. The proportions of the stocks with increase in these variables also were moderate, around 60 to 70 percent. The increases are generally significant using both the parametric paired $t$ test and non-parametric sign test. Conversely for the high-priced stocks (especially if they are frequently traded), all three measures of trading volume decreased on average after the JSX tick size reduction. The proportions of the stocks with decrease in these variables are also high, around 65 to 85 percent. The in- 
Purwoto \& Tandelilin-The Impact of the Tick Size Reduction on Liquidity

Table 8. Comparison of Pre- and Post-Reduction Trading Activity by Price and Volume

Price Level

\section{Volume Level}

\begin{tabular}{cc}
\hline Low & High \\
& \\
10.66 & 63.76 \\
36.70 & 123.69 \\
26.04 & 59.93 \\
$3.11 * * *$ & $3.35 * * *$ \\
63.83 & 73.47 \\
$1.75 *$ & $3.14 * * *$ \\
& \\
17.64 & 220.63 \\
13.45 & 153.72 \\
-4.19 & -66.91 \\
-1.48 & $-3.52 * * *$ \\
40.82 & 16.67 \\
-1.14 & $-4.47 * * *$
\end{tabular}

\section{B: Share Volume}

$\begin{array}{cl} & \text { Before } \\ & \text { After } \\ \text { Low } \quad \text { Change } \\ & t \text {-statistic } \\ & \% \text { of stocks with increase } \\ & z \text {-statistic } \\ & \\ & \text { Before } \\ & \text { After } \\ & \text { Change } \\ & t \text {-statistic } \\ & \% \text { of stocks with increase } \\ & z \text {-statistic }\end{array}$

$$
\begin{gathered}
155,399.44 \\
540,009.37 \\
384,609.93 \\
2,09 * * \\
61.70 \\
1.46
\end{gathered}
$$

$109,637,99$

$85,404.76$

$-24,233.24$

$-0.91$

30.61

$-2.57 * *$
$2,865,094.75$

$6,166,387.03$

$3,301,292.27$

$2.68 * * *$

65.31

$2.00 * *$

$3,733,974.70$

$2,299,394.59$

$-1,434,580.11$

$-2.97 * * *$

12.50

$-5.05 * * *$

\section{C: Rupiah Volume}

$\begin{array}{ll} & \text { Before } \\ \text { Low } & \text { After } \\ & \text { Change } \\ & t \text {-statistic } \\ & \% \text { of stocks with increase } \\ & z \text {-statistic }\end{array}$

$43,737,936.93$

$150,402,450.60$

$106,664,513.67$

$2.01 * *$

57.45

0.86
$744,382,130.70$

$1,411,797,128.27$

$667,414,997.57$

$2.01 * *$

67.35

$2.29 * *$ 
Continued from Table 8

\begin{tabular}{|c|c|c|c|}
\hline \multirow{2}{*}{\multicolumn{2}{|c|}{ Price Level }} & \multicolumn{2}{|c|}{ Volume Level } \\
\hline & & Low & High \\
\hline \multirow{6}{*}{ High } & Before & $214,472,558.31$ & $6,783,747,681.07$ \\
\hline & After & $154,353,113.45$ & $3,208,008,280.01$ \\
\hline & Change & $-60,119,444.86$ & $-3,575,739,401.06$ \\
\hline & $t$-statistic & $-1.87 *$ & $-3.69 * * *$ \\
\hline & $\%$ of stocks with increase & 32.65 & 12.50 \\
\hline & $z$-statistic & $-2.29 *$ & $-5.05 * * *$ \\
\hline
\end{tabular}

* Significant at the 0.10 level;

** Significant at the 0.05 level;

*** Significant at the 0.01 level.

creases are generally significant using both the parametric paired $t$-test and nonparametric sign test. ${ }^{9}$

The table compares daily trading activity in price/volume quadrant of the prereduction period (May 1 to June 30, 2000) and post-reduction period (July 4 to August 31,2000$)$. Also reported is the average change between the two periods. The $t$-statistic is calculated by using a parametric paired $t$-test to test the null hypothesis that the mean change is zero. The $z$-statistic is calculated by using a non-parametric sign test to test the null hypothesis that the percentage of the stocks that experienced an increase equals 50 .

To better understand the impact of the tick size reduction on trading activity, this study draws time-series plots of the daily averages of the number of trades in Figure 3. For share volume and rupiah volume, the time series plots show a simi- lar pattern and are not reported. Panel A of this figure reveals less significant structural changes in trading activity surrounding the JSX tick size reduction. In Panel $B$, $C, D$, and $E$ of this figure, however, timeseries plots clearly show a pattern: trading activity increased for low-priced stocks, but decreased for high-priced stocks (especially if they are frequently traded). These time series plots are consistent with previous findings.

This study has documented an increase in the number of trades, share volume, and rupiah volume for low priced stocks. These results are consistent with the arguments of Harris (1994) and the proponents of tick size reduction (Ricker 1998; MacKinnon and Nemiroff 1999). For high price stocks, however, this study shows a reduction in the number of trades, share volume, and rupiah volume. These findings are amazing since high priced

\footnotetext{
${ }^{9}$ To assure these findings, this study also analyzed the change in trading volume by dividing the sample stocks into four quartiles formed by average pre-reduction daily closing price. The result in share volume is shown in the following table. The results in the number of trades and rupiah volume are similar. These findings clearly show that the lower a stock's price, the greater the significant increase in volume. On the contrary, the higher a stock's price, the greater the significant decrease in volume.
} 
Purwoto \& Tandelilin - The Impact of the Tick Size Reduction on Liquidity

Figure 3. Time-Series Plot of the Number of Trades

A: All Stocks in the Sample

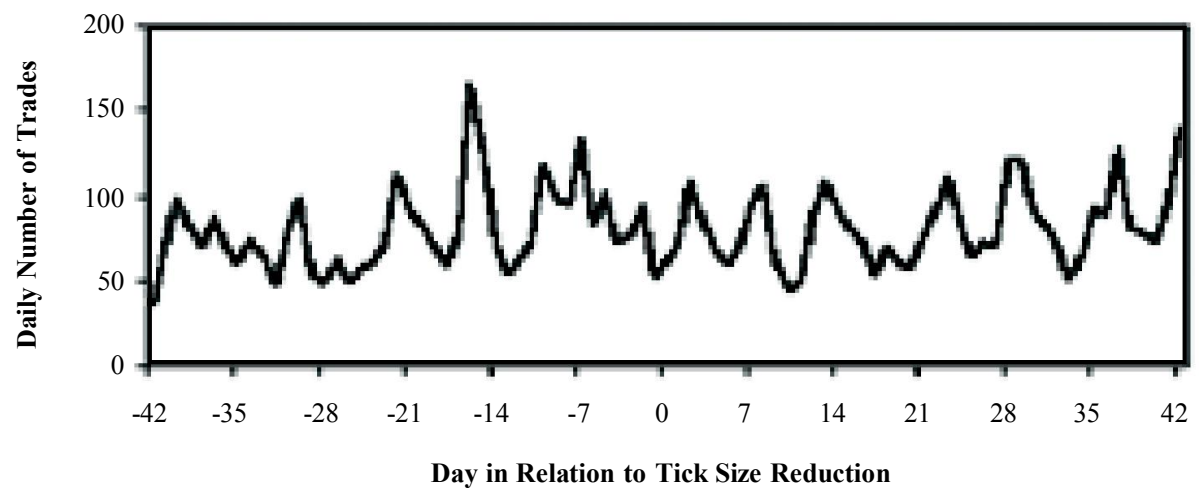

B: Low Price, Low Volume

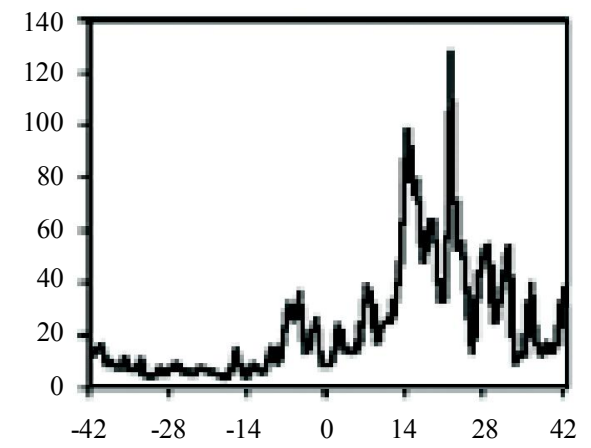

D: High Price, Low Volume

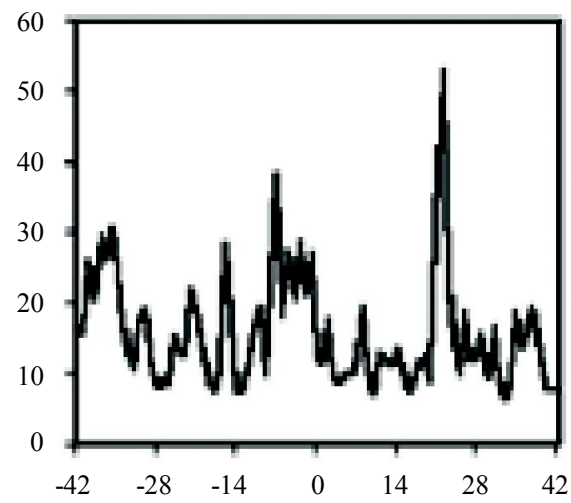

B: Low Price, High Volume

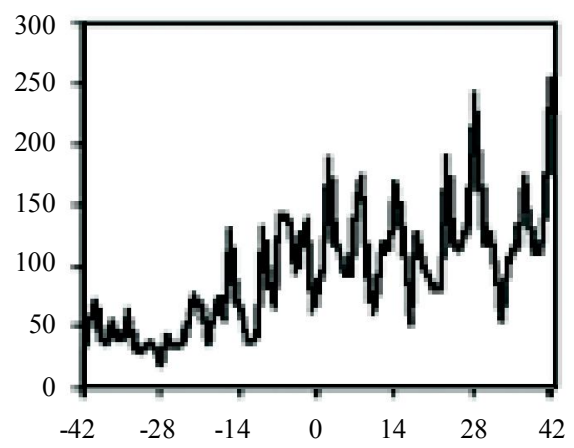

E: High Price, High Volume

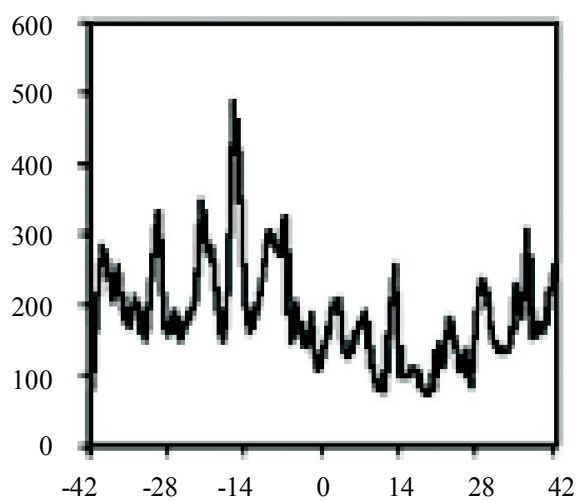


stocks (especially for frequently traded) also decreased in spreads. In this section, we provide a possible explanation for the opposing results.

Some authors, notably Niemeyer and Sandas (1994) and Angel (1997), explain that a relatively low tick size implies low roundtrip trading costs for traders. However at the same time it means low compensations for providing market-making service. It is important to note here that the absolute tick size is not the issue, but rather the proportional relationship of the tick size to the stock price. Since the JSX uses a single absolute tick size that applies to all stocks, the higher the price of stocks traded, the smaller in economic terms the tick of Rp5.00 is for investors. The result is a decrease in the investors' willingness to trade and, consequently, a decrease in trading activity. On the other hand, the tick Rp5.00 for low price stocks generally remain large now in economic terms, therefore the reduction in trading cost induces trading activity. In addition, the lower trading profits of a reduced tick size might be offset by profits from increased trading activity.

This explanation also completes the explanation of the empirical results of Chan and Hwang (1998). Using data from the Stock Exchange of Hong Kong, they found that when tick sizes are smaller, the trading activity increases only for lowerprice stocks, but does not affect the trading activity for larger-price stocks. It is likely that this is because the Stock Exchange of Hong Kong uses a tick size that is a step function of the share price. Therefore, the current tick size of higher-priced stocks is perhaps still adequate in economic terms that a reduction does not cause a decline in the trading activity.

\section{Did Liquidity Increased After the JSX Reduced Its Tick Size?}

Amihud and Mendelson (1988) explain that illiquidity of the assets is reflected in the difficulties with trading them. Several researchers (for example Harris 1999) emphasize liquidity as the ability to trade at low cost when investors want to trade. Thus, liquidity refers to quickness and how cheapness for both stocks and investors. This subsection draws conclusions about stock liquidity changes after the JSX tick size reduction.

This study finds that spreads significantly decreased. Literature has long noted that trading cost measured by spreads reflects liquidity (for example Cohen et al. 1981; Amihud and Mendelson 1988). Therefore, this finding may be interpreted as an increase in liquidity after the JSX reduced its tick size (though it is better to conclude that liquidity was simply not decreased). This conclusion is similar to the standard conclusion of other research, for example Porter and Weaver (1997) in the Toronto Stock Exchange, Ronen and Weaver (1998) in the American Stock Exchange, Ricker (1998) in the New York Stock Exchange, Besembinder (1997) in the Nasdaq, and Lau and McInish (1995) in the Singapore Stock Exchange.

However, the literature also notes that overall liquidity should include not quantity dimension but price (spread) dimension. More depth implies liquidity increase since it means a larger ability to accept order flow without large change in price(Madhavan 1992). An empirical study by Ahn and Cheung (1999) in the Stock Exchange of Hong Kong also shows that limit order traders respond by adjusting to both spread and depth, consistent with the 
findings of Lee et al. (1993) on the New York Stock Exchange. Since both of srpead and depth decreased, the effect of the tick size reduction on liquidity is therefore ambiguous. Spread reduction clearly benefits small investors that trade at the best quote. For large investor, however, spread reduction does not yet imply a reduction in trading costs. Therefore, as Harris (1994) and Niemeyer and Sandas (1994) point out, spread reduction does not necessarily mean that liquidity increases.

MacKinnon and Nemiroff(1999) and Chan and Hwang (1998) emphasize for using the trading activity as a main indicator of liquidity. The increase of trading activity reflects the increase of investor interest in stocks and exchange. An as most emerging markets face thin trading, JSX statistics (1999) show that the fifty most actively traded stocks of nearly all 275 common stocks have accumulated more than 80 percent of total trading value. This study has documented that all the trading activity measures, e.g., number of trades, share volume, and rupiah volume, increased for low-priced stocks. On the contrary, trading activity decreased for high-priced stocks. This evidence indicates that the JSX tick size reduction was better for higher-priced stocks.

However, given that tighter spreads and smaller depths have opposite implications for market liquidity, a question that remains unanswered is, "What is the net impact of the JSX tick size reduction on trading costs?" Alternatively, "Does it cost less to execute the same quantity of shares after the tick size reduction?" Ahn et al. (1998) address these questions by examining the change in the depth-to-spread ratio, which measures the tradeoff between the spread and the depth. Ricker (1998) and Bacidore (1997) also use this ratio to measure liquidity and solve the ambiguity surrounding the changein spread and depth. According to Harris (1997), the depth-tospread ratio can be used to approximate the size of an order that would move prices one percent if the relationship between total size and price is linear. Intuitively, this ratio measures whether the decrease in depth is larger or smaller than the decrease in the spread.

Following these previous studies, we calculate the depth-to-spread ratio using the average of ask-depth and bid-depth divided byrupiah (and percentage) spread. If trading activity is related to net trading cost, it can be expected to find that the ratio is positive for low-priced stocks but negative for high-priced stocks. Table 9 shows the results of both depth-to-spread ratios in the price/volume quadrant. The pattern supports that the key variable influencing the variation is the price of the stock. Although infrequently traded stocks were largely unaffected, high-priced frequently traded stocks tended to increase significantly; conversely, low-priced frequently stocks experienced a significant decline in the depth-to-spread ratio. These results strengthen the evidence of trading activity and indicate that the tick size reduction on the JSX had opposite effects depending on the price level of the stock. Thus these suggest that the JSX tick size reduction increased the liquidity oflow-priced stocks, but decreased the liquidity of high-priced stocks.

The table compares depth-to-spread ratio in price/volume quadrant of the prereduction period (May 1 to June 30, 2000) and post-reduction period (July 4 to August 31,2000$)$. Also reported is the average change between the two periods. The $t$-statistic is calculated by using a parametric paired $t$-test to test the null hypothesis that the mean change is zero. The $z$-statistic is calculated by using a non-parametric 
Gadjah Mada International Journal of Business, May 2004, Vol. 6, No. 2

Table 9. Comparison of Depth-to-Spread Ratio by Price and Volume

Price Level

\section{A: Depth-to-Rupiah Spread Ratio}

$\begin{array}{ll} & \text { Before } \\ \text { Low } \quad \text { After } \\ \text { Change } \\ t \text {-statistic } \\ \% \text { of stocks with increase } \\ z \text {-statistic } \\ \\ \text { Before } \\ \text { After } \\ \text { Change } \\ t \text {-statistic } \\ & \% \text { of stocks with increase } \\ z \text {-statistic }\end{array}$

\section{B: Depth-to-Percentage Spread Ratio}

\begin{tabular}{rlrc} 
& Before & $17,617.48$ & $149,946.45$ \\
\multirow{3}{*}{ Low } & $29,266.93$ & $302,020.60$ \\
& After & $11,649.45$ & $152,074.15$ \\
& Change & 1.53 & $4.21 * * *$ \\
& -statistic & 48.94 & 59.18 \\
\% of stocks with increase & 0.00 & 1.14 \\
$z$-statistic & $11,267.96$ & $268,800.66$ \\
Before & $11,321.58$ & $200,029.50$ \\
& After & 53.62 & $-68,771.16$ \\
& Change & 0.03 & $-2.48 * *$ \\
& $t$-statistic & 42.86 & 16.67 \\
\% of stocks with increase & -0.86 & $-4.47 * * *$ \\
& $z$-statistic & & \\
\hline
\end{tabular}

* Significant at the 0.10 level;

** Significant at the 0.05 level;

*** Significant at the 0.01 level;

\begin{tabular}{ll}
\multicolumn{2}{c}{ Volume Level } \\
\hline Low & High \\
\hline
\end{tabular}

$7,493.98$

$70,698.59$

$13,169,32$

$183,435.05$

$5,675.34$

$112,736.46$

1.58

53.19

$3.98 * * *$

57.14

0.86

966.93

$26,261.90$

$1,031.35$

$23,444.79$

64.42

$-2,817.11$

$-0.75$

16.67

36.74

$-1.71 *$

$-4.47 * * *$ 
sign test to test the null hypothesis that the percentage of the stocks that experienced an increase equals 50 .

\section{Conclusion and Recommendations}

This study uses daily data from the Jakarta Stock Exchange, a limit order driven market with a consolidated open limit order book, to examine the impact of the tick size reduction on the bid-ask spread, market depth, and trading activity. The tick size reduction on JSX resulted in a reduction in rupiah spread and percentage spread. However, depth also decreased significantly following the tick size reduction. These evidences from the JSX are not surprising since they are consistent with Harris (1994) and empirical studies of tick size reduction on US and Canada markets. Thus it ends the hesitancy of the impact of the tick size reduction in a market without market maker.

The tick size reduction on the JSX had also an impact on trading activity. In contrast to previous studies, this study finds that the key variable in determining the difference in the performance is the price of the stock. Trading activity increased for low-price stocks, on the contrary, decreased for high-priced stocks. The possible explanation is that the absolute tick size Rp5.00 is too small in economic terms for JSX higher priced stocks, so those decrease the investors' willingness to trade.

The overall results suggest that the tick size Rp5.00 is better for low-priced stocks, but worse for high-priced stocks. Therefore, this study recommends that the JSX moves from using a single absolute tick size to using a tick size that is a step function of the stock price. The tick size of Rp5.00 is applied only to low-priced stocks, but the tick size Rp5.00 for high-priced stocks could be increased to approximately the pre-reduction size. Since exchanges earn a substantial part of their income based on trading volume, by applying this recommended rule, the JSX will be more concerned with creating a trading mechanism that will increase the liquidity of higher priced stocks. Moreover, most exchanges in Asia, Australia, and Europe also designed without market maker - use a minimum price tick that varies depending on the price of the stock.

Corporations should also be interested in tick size since as Amihud and Mendelson (1988) noted, increasing liquidity implies a reduction in the cost of capital, thereby increasing the firm value. This study recommends to JSX listed companies, especially to those whose stocks are actively traded at high prices, to split their stocks (or stock dividend). This recommendation is not odd in a microstructure-based explanation for stock splits. Some authors, notably Angel (1997), argue that splits are intended by companies to move relative ticks to desired levels. There is a note, of course, only if JSX continues to use a single absolute tick size of Rp5.00.

Finally, investors or other market participants in the JSX should be careful when using previous trading strategies developed when the tick size was Rp25.00. The tick size reduction is beneficial for small traders since they will benefit from the narrower bid-ask spread and depth (Niemeyer and Sandas 1994; Porter and Weaver 1998; Venkataraman 1999). The strategy of breaking a large order into smaller orders is recommended if one wishes to benefit from the spread reduction and defend against quote matchers. Dealers must also be concerned with this issue. A large part of dealer profits comes 
Gadjah Mada International Journal of Business, May 2004, Vol. 6, No. 2

from the spread. Since the JSX tick size reduction decreased spread, dealer profits may decrease too. The lower trading prof- its of a reduced tick size must be offset by profits from increased trading volume by traders who see the lowering trading cost.

\section{References}

Ahn, H., and Y. Cheung. 1999. The Intraday Patterns of the Spread and Depth in a Market without Market Makers: The Stock Exchange ofHong Kong. Pacific-Basin Finance Journal 7: 539-556.

Ahn, H., C. Cao, and H. Choe. 1998. Decimalization and Competition among Stock Exchange Markets: Evidence from the Toronto Stock Exchange Cross-listed Securities. Journal of Financial Markets 1: 51-87.

Aitken, M., and A. Frino. 1996. The Determinants of Market Bid Ask Spreads on The Australian Stock Exchange: Cross-sectional Analysis. Accounting \& Finance 36: 51-63.

Amihud, Y., and H. Mendelson. 1988. Liquidity and Asset Prices: Financial Management Implications. Financial Management 17: 5-15.

Bacidore, J. 1997. The Impact of decimalization on Market Quality: An Empirical Investigation of the Toronto Stock Exchange. Journal of Financial Intermediation 6: $92-120$

Bessembinder, H. 1997. Endogenous Changes in the Minimum Tick: An Analysis of Nasdaq Securities Trading near Ten Dollars. Working Paper, Arizona State University.

Bessembinder, H. 1999. Trade Execution Costs on Nasdaq and the NYSE: A Post-Reform Comparison. Journal of Financial and Quantitative Analysis 32: 287-310.

Chan, K., and C. Hwang. 1998. The Impact of Tick Size on Market Quality: An Empirical Investigation of the Stock of Hong Kong. Working Paper, Hong Kong University of Science and Technology.

Cohen, K., S. Maier, R. Schwartz, and D. Whitcomb. 1981. Transaction Costs, Order Placement Strategy, and Existence of the Bid-Ask Spread. Journal of Political Economy 89: 287-305.

Goldstein, M., and K. Kavajecz. 2000. Eighths, Sixteenths and Market Depth: Changes in Tick Size and Liquidity Provision on the NYSE. Journal of Financial Economics 56: $125-149$.

Harris, L. 1994. Minimum Price Variations, Discrete Bid-Ask Spreads, and Quotation Sizes. Review of Financial Studies 7: 149-178.

Harris, L. 1997. Decimalization: A Review of Arguments and Evidence. Working Paper, Marshal School of Business at University of Southern California. 
Purwoto \& Tandelilin-The Impact of the Tick Size Reduction on Liquidity

Harris, L. 1999. Trading in Pennies: A Survay of the Issues. Working Paper, Marshal School of Business at University of Southern California.

Huang, R., and H. Stoll. 1999. Tick Size, Bid-Ask Spreads and Market Structure. Working Paper, Owen Graduate School of Management Vanderbilt University.

Jones, C., and M. Lipson, 2000. Sixteenth: Direct Evidence on Institutional Execution Costs. Journal of Financial Economics 59, Forthcoming.

Lau, S., and T. McInish. 1995. Reducing Tick Size on the Stock Exchange of Singapore. Pasific-Basin Finance Journal 3: 485-496.

Lee, C., B. Muclow, and M. Ready. 1993. Spreads, Depths, and the Impact of Earnings Information: An Intraday Analysis. Review of Financial Studies 6: 345-374.

MacKinnon, G., and H. Nemiroff. 1999. Liquidity and Tick Size: Does Decimalization Matter? Journal of Financial Research 22: 287-299.

Madhavan, A. 1992. Trading Mechanism in Securities Markets. Journal of Finance 47: 607-641.

McInish, T., and R. Wood. 1992. An Analysis of Intraday Patterns in Bid/Ask Spreads for NYSE Stocks. Journal of Finance 47: 753-762.

Niemeyer, J., and P. Sandas. 1994. Tick Size, Market Liquidity and Trading Volume: Evidence from the Stockholm Stock Exchange. Working Paper, Stockholm Shool of Economics.

Porter, D., and D. Weaver. 1997. Tick Size and Market Quality. Financial Management 26: 5-26.

Ricker J. 1998. Breaking the Eighth: Sixteenths on the New York Stock Exchange. Working Paper, 1730 Filbert Street No. 105, San Fransisco.

Ronen T., and D. Weaver. 1998. The Effect of Tick Size on Volatility, Trader Behavior, and Market Quality. Working Paper, Rutgers University.

Smith, J., 1998. The Effects of Order Handling Rules and 16ths on Nasdaq: a Crosssectional Analysis. NASD Working Paper 98-02.

Tinic, S., and R. West. 1974. Marketability of Common Stocks in Canada and the USA: A Comparison of Agent versus Dealer Dominated Markets. Journal of Finance 29: 729-746.

Venkataraman, K. 1999. A Tale of Two Cities: An Analysis of Execution Costs on Paris and New York. Working Paper, Arizona State University. 